\title{
CALGARY BLUEBIRD TRAIL - 1977
}

HAROLD W. PINEL, 1017-19 Ave. N.W., Calgary, Alberta, and JOHN R. BIDDELL, 1212 Belavista Crescent S.W., Calgary, Alberta

In the spring of 1977, the Calgary Bluebird Trail was again prepared for the upcoming nesting season. The 400 nesting boxes were cleaned out, sprayed with a $10 \%$ creolin solution, and repaired or replaced, as required. Each box was checked and the contents recorded four times during the nesting season. $A$ number of adult and young Mountain Bluebirds and Tree Swallows were banded.

Of the 400 houses, 43 were vandalized before nesting began, 15 after nesting started and only 8 were unoccupied on all visits, leaving 334 boxes used by birds. Excluding the 43 vandalized before the nesting season, $93.5 \%$ of the available nesting boxes were occupied. There were 391 bird nests, 1 Red Squirrel nest, and 3 Deer Mouse nests in the 334 boxes, a few of the houses being used up to four times.

Table 1 analyzes the nesting success and losses for 1977. The average clutch size for Mountain Bluebirds was 5.13 and the Tree Swallows, 5.68. In 42 nest boxes there were two or more broods by the same species - 29 were House Sparrows and 13, Mountain Bluebird. Different species nested in the same box 60 times, as follows: sparrow then swallow, 21; sparrow then bluebird, 1; swallow then sparrow, 4; swallow then wren, 3 ; bluebird then sparrow, 1 ; bluebird then swallow, 27; bluebird then swallow then bluebird, 1; sparrow then swallow then sparrow, 2 .

The total losses for all species from egg-laying to young leaving the nest was $930(46.7 \%)$ of which $483(24.2 \%)$ were House Sparrow losses due to destruction by the authors. Interspecific competition and egg infertility were the major causes for losses by the other species.

In 1977, 668 birds were banded of which 258 were Mountain Bluebirds and 410 were Tree Swallows. This was the first year that Black-capped Chickadees nested successfully in the boxes.

Table 1. SUMMARY OF NESTING SUCCESS BY SPECIES, CALGARY BLUEBIRD TRAIL, 1977. (Numbers in parentheses are losses from the previous stage)

\begin{tabular}{|c|c|c|c|c|c|c|}
\hline Species & Nests & $\begin{array}{l}\text { Eggs } \\
\text { laid }\end{array}$ & $\begin{array}{l}\text { Eggs } \\
\text { hatched }\end{array}$ & $\begin{array}{l}\text { Young } \\
\text { fledged }\end{array}$ & $\begin{array}{l}\text { Young } \\
\text { Left } \\
\text { Nest }\end{array}$ & $\begin{array}{l}\% \text { of eggs } \\
\text { producing } \\
\text { fledged } \\
\text { young }\end{array}$ \\
\hline $\begin{array}{l}\text { Mountain } \\
\text { Bluebird }\end{array}$ & 104 & 534 & $347(187)$ & $323(24)$ & $323(0)$ & 600 \\
\hline Tree Swallow & 165 & 938 & $755(183)$ & $703(52)$ & $703(0)$ & $75 \%$ \\
\hline House Sparrow & 116 & 485 & $135(350)^{*}$ & $2(133)^{*}$ & $2(0)$ & - \\
\hline House Wren & 4 & 22 & $22(0)$ & $21(1)$ & $21(0)$ & $95 \%$ \\
\hline $\begin{array}{c}\text { Black-capped } \\
\text { Chickadee }\end{array}$ & 2 & 14 & $14(0)$ & $14(0)$ & $14(0)$ & $100 \%$ \\
\hline TOTALS & 391 & 1,993 & $1,273(720)$ & $1,063(210)$ & $1,063(0)$ & $53 \%$ \\
\hline
\end{tabular}

*Destroyed by authors 